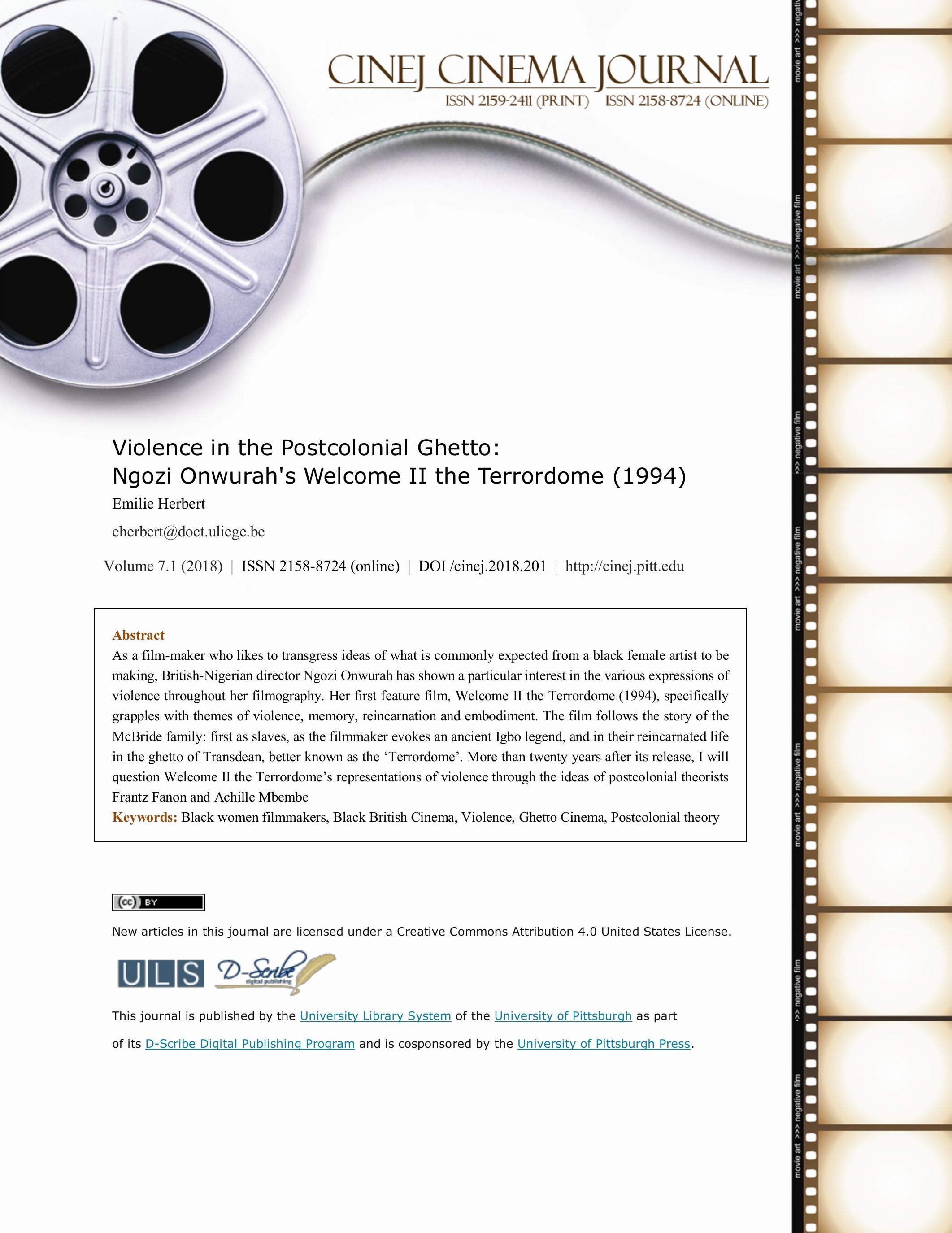




\section{Violence in the Postcolonial Ghetto: Ngozi Onwurah's Welcome II the Terrordome (1994)}

\section{Emilie Herbert}

\section{Introduction}

When her first (and sole) feature-film Welcome II the Terrordome was screened at the British Film Institute in June 2017, Ngozi Onwurah was presented as a "forgotten pioneer of Black British Film (Varaidzo, 2017). Indeed, although Onwurah has a respectable filmography of more than 15 films - most of which of short format - her work still seems to be largely unknown and underrated. Her films have regularly been described as transgressive and controversial, and in Welcome II the Terrordome, a dystopia set in the imaginary ghetto of 'Transdean', Onwurah grapples with themes of violence, memory, reincarnation and embodiment. Causing quite a controversy at the time of its release, the film does certainly leave no one indifferent but seems to have inspired more positive readings in the past few years. I will attempt to critically reassess the film in regards to the mixed reviews it received at the time, through an analysis of its depiction of violence - with the help of postcolonial theorists such as Frantz Fanon, Achille Mbembe, Abdul JanMohamed and Paul Gilroy. This will enable me to explore the possibilities of emancipation and agency that lie within these representations.

\section{Ngozi Onwurah and Welcome II the Terrordome}

Born in 1966 in Nigeria to a black Nigerian father and a white British mother, Ngozi Onwurah arrived in the UK aged nine, after the civil war has teared her native country apart. After a troubled childhood in Newcastle-Upon-Tyne in Northern England where she and her siblings suffered from racist discriminations - an experience she explored in her first short-film Coffee 
Coloured Children in 1988 - she studied Film at the prestigious Saint Martin's School of Art in London and, later on, at the National Film and Television School. Onwurah has never been willing to compromise much when it comes to filmmaking: "What they expect a Black woman film-maker to be making is definitely not the kind of movies I want to make" (Foster, 1997, p. 38), adding in an interview that she prided herself on the fact that her films featured "Black women with guns" (Foster, 1997, p. 38). In fact, the filmmaker has shown a particular interest in the various expressions of violence throughout her filmography : mentions of psychological and emotional violence can be found in films such as Coffee Coloured Children (1988, 15 minutes, colour), And Still I Rise (1992, 30 minutes, colour), The Flight of the Swan (1994, 12 minutes, colour), or Shoot the messenger (2006, 90 minutes, colour); when films like White Men Are Cracking Up (1994, 25 minutes, colour) and Welcome II The Terrordome more specifically feature physical forms of violence. The latter has particularly attracted harsh criticism and answering the vehement reviews Welcome II The Terrordome received at the time of its release, Onwurah defended herself by stating: "I don't understand why people are so concerned with violence in the movies and seem not to be so concerned about violence in the real world. They spend more of their energies criticizing violence in the movies. I mean, my movies will always be explicit because I think that, as a black woman, what has happened historically to my people and my sex has never been seen [...] I want to really spell it out and show it in my films "(Stringer, 1995, p. 38-39). As such, a sense of urgency can be felt from Onwurah's films, echoing Martina Attille's (another great black British female director) claim that 'Sometimes, one can't afford to hold anything back for another time, another conversation or another film" (Mercer, 1988, p. 12). Onwurah's position as a black female filmmaker does therefore in part explain the sometimes unfiltered and transgressive nature of her work. If Welcome II the Terrordome is de facto a violent film because it depicts violence, it is interesting to note that the film can also be interpreted as an answer to a symbolic violence that 
has historically silenced the voice of marginalised groups of people, like in this case black women. Being the first black British woman to have a feature film theatrically released in the UK (as of 2018, there are only four black British women in the UK - Ngozi Onwurah, Amma Asante, Debbie Tucker Green and Destiny Ekaragha - that have had their feature films released in cinemas), Ngozi Onwurah is a "warrior queen" such as Amma Asante would describe "any woman who chooses to enter into a world that is predominantly male [and in the case of the film industry, I would argue also white] and traditionally not seen as the territory of the 'woman"” (Mayer, 2016, p. 97). And the "warrior queen" definitely displays her taste for battle in Welcome II the Terrordome, a film she largely financed through private sources (with the help of Channel4 and the production company Metro Tartan for post-production) and which she painfully directed over a period of three years. Sharing its title with a song from the hip hop group Public Enemy, the film was developed first as a short film before expanding into a 50-minute film and then a feature. It follows the story of the McBride family: in the opening sequence of the film, the McBrides appear as slaves as they reenact an ancient Igbo legend recounting the mass suicide of a group of slaves who walked into the sea in order to escape a life of slavery. The story, also known as "Igbo Landing", has incidentally inspired many black women artists like the author Toni Morrison, the filmmaker Julie Dash or more recently the pop singer Beyoncé. White characters, playing the slave masters, also feature in this opening sequence and Onwurah then reimagines both the McBrides and the white slaveowners in a reincarnated life in the ghetto of "Transdean', better known as the "Terrordome". If the voice-over who narrates the film is masculine, the film mainly follows two female characters: Angela (Suzette Llewellyn), a black woman who goes on a vengeful killing spree after her teenage son has been murdered by a gang of white youths; and Jodie (Saffron Burrows), a pregnant white woman whose black boyfriend, Spike (Valentine Nonyela), is involved in drug dealing in the 
Terrordome. In the course of a night, a series of dramatic events unfold and Angela is eventually arrested, tortured and hanged by the police, while Jodie's jealous ex-(white) boyfriend beats her and provokes the loss of her baby. The Blue Posse, Spike's (and Angela's husband, Radical) black gang, then takes over a mainstream television station and begins to broadcast its manifesto for Black Liberation.

Described by the press as a mix of "Boyz $\mathrm{N}$ the Hood, rap videos, Sergio Leone, experimental cinema" (Roddick, 1994, p. 28), "Mad Max and Blade Runner" (Beard, 2000), or recalling Melvin Van Peebles' "Sweet Sweetback's Baadasssss Song" (Elley, 1995), the film mainly draws inspiration from Onwurah's personal experiences (Jodie's violent miscarriage in the film was for example inspired by a friend of hers who had gone through the same trauma (Foster, 1995, p. 293) as well as true events such as the Howard Beach incident and the Rodney King beating verdict in the USA and - this is my assumption - the killing in 1993 of the young Stephen Lawrence in London - all racially motivated attacks against young black men. Seen with more contemporary eyes, one cannot help but also think of the killings that led to the Black Lives Matter movement in the US. Radical's complaint at the end of the film truly echoes what BLM is all about when he says that he is "sick of going to funerals of Black men who have been murdered by white men". The fact that the film still resonates today can explain why it has been reconsidered and offered new screenings in the UK and the USA in the past few years. But in 1995, mostly because of bad publicity - with Paul Gilroy even calling the film "politically repugnant", "artistically and conceptually inept", "fascist", and "anti-feminis[t]" (Gilroy, 1995, p. 18) - Welcome II the Terrordome only took $5000 £$ at the box-office. Problems of continuity and budgetary restrictions surely didn't help the film to seduce critics and audience alike, but if the film certainly has flaws and weaknesses, I will also argue that its aesthetic and epistemological value has been largely 
ignored at the time precisely because its transgressive representations of violence have been found overwhelming.

\section{New forms of segregation : the Black ghetto}

In the Terrordome, violence is exerted through language, but also and mostly through physical torture, revenge, and eventually political uprising against white supremacy. In fact, one of the criticism the film received was related to its depiction of a segregated society where interracial relationships are inevitably bound to fail. But the possibilities of racial intimacy are actually often questioned in ambivalent ways in Onwurah's filmography ${ }^{1}$ and as Anne Ciecko notices, in Welcome II the Terrordome "it is unclear where the film stands on race mixing because of its sympathy for the plight of the white character Jodie" (Ciecko, 1996, p. 70). In the film, Jodie and Spike's love story seems to be largely disapproved by both black and white communities, and is described quite vulgarily as a case of "jungle fever". But Jodie is probably one of the bestdefined character in the film, and certainly appears as one the spectator feels empathy for. Victim of violence as a "nigga-lovin' type" - as she is described by a white character in the story - she's also the only one who does not find any kind of redemption at the end of the film. It seems that more than Spike, Jodie's position in the Terrordome is precarious: too white for the black community, yet not really white anymore for her racist ex-boyfriend - and, as a matter of fact, current boyfriend Spike, who assures her that "that's a black baby you got in you, you're one of us now!". I think that the film's standpoint on interracial relationship is not so much on its undesirability, as much as a critic of the external factors that render it difficult to maintain - and

\footnotetext{
${ }^{1}$ See The Body Beautiful; White Men Are Cracking Up; and I Bring You Frankincense.
} 
given Onwurah's situation as the child of a mixed-race marriage, and having herself been married to a white man for the past 20 years, this assumption is, I would argue, plausible. If there's a clear rivalry between black and white communities in the film, black gangs confront each other in extremely violent ways too. On the other hand, a brutal black police officer is killed by Angela, as he is shown as the embodiment of an external oppressive (white) system. What is eventually being targeted by the Blue Posse are institutions: the police, the media, and the white gang - symbolizing the economic oppression of the dominant society. The fact that neither whites nor blacks, and as a matter of fact neither men nor women, are protected from violence in the Terrordome - either by being a victim or a perpetrator of it - probably shows how Onwurah somehow attempted to disrupt simplistic binary divisions between who are supposedly the 'good guys' and who are the bad ones - even though the critic of the white supremacy (from slavery times to more contemporary settings) inevitably points whites as the perpetrators of oppression in the film.

When the ghetto first appears on the screen, the camera is set inside a police car which slowly moves through the gates of the Terrordome and inside the area. The ghetto is represented as a fixed, closed space where the audience is invited to enter (through that slow camera move), but what exists outside of it is never shown in the film. White people only seem to step in to police, control and regulate black bodies (and white bodies who transgress ideas of racial exclusivity, as in Jodie's case). But if spatiality is central to the depiction of the ghetto, geographically speaking, it is unclear where the Terrordome is set : all the characters speak in British accents, yet the film features many american influences and numerous african elements firmly put the film into a kind of transnational, "Black Atlantic" - to borrow Paul Gilroy's term - frame. The Terrordome actually bears great similarities with the colonized's sector Fanon describes in The Wretched of the Earth: "a disreputable place inhabited by disreputable people. You are born anywhere, anyhow. You die anywhere from anything. It's a world with no space, people are piled one on top of the other, the 
shacks squeezed tightly together" (Fanon, 2004, p. 4). This quite hellish description of the colonized's sector, where life and death seem to be intertwined in a morbid dynamic, is echoed by the description of the ghetto in the film as a purgatory : "A "no man's land, a place where neither our spirits were free, nor our bodies dead. This is the transit zone between two worlds". But if the purgatory is a space (it is a "transit zone"), it also acts as a temporal link between past slavery times (what we see at the beginning of the film) and a future black liberation (what we see at the end of the film). Furthermore, the description of the Terrordome as a "no man's land" underlines the idea that its inhabitants are never really neither alive nor dead, like zombies. Fanon evokes the idea that the colonized are existing in a sort of 'dead time' (Fanon, 2008), when Abdul JanMohamed describes the postcolonial ghetto as inhabited by "death-bound subjects" (JanMohamed, 2005) who are "formed, from infancy on, by the imminent and ubiquitous threat of death" (JanMohamed, 2005, p. 2). The postcolonial ghetto therefore shares with the colonized's sector both the fixity of its borders and the fluidity of its temporal parameters, which together naturalize violence as a feature of life in these spaces. This is how necropolitics are developed in these spaces, according to the Cameroonian political and postcolonial theorist Achille Mbembe. Mbembe explains: "living in a state of terror [...] is not new. Historically, the strategy of dominant states have always been to spatialize and to discharge terror by confining its most extreme manifestations in a third-space racially stigmatised - the plantation, the colony, the camp, the ghetto or, like in contemporary America, the prison" (Dorlin, 2007, p. 144-145). Drawing on Foucault's concept of biopower and biopolitics, Mbembe develops the idea of the necropower as a specific terror formation, where "contemporary forms of subjugation of life to the power of death profoundly reconfigure the relations among resistance, sacrifice, and terror" (Mbembe, 2003, p. 39), and where "in the logic of survival one's horror at the sight of death turns into satisfaction that 
it is someone else who is dead" (Mbembe, 2003, p. 36). In his essay Necropolitics, he takes the example of the colonial and neocolonial spaces - or what he names the "late-modern colonial regimes" (although he mentions situations as varied as the Nazi camps, slavery, apartheid in South Africa or the colonial occupation in Gaza and the West Bank) - to illustrate the way necropolitics works. Mbembe explains how biopower comes to relation with notions of sovereignty and the state of exception. He begins his essay by stating that "the ultimate expression of sovereignty resides, to a large degree, in the power and the capacity to dictate who may live and who must die" (Mbembe, 2003, p. 11). But Mbembe looks at the combination of biopower and racism as ways for a sovereign state to exercise a right to kill on certain individuals. As such, he specifically looks at figures of sovereignty whose central project is "the generalized instrumentalization of human existence and the material destruction of human bodies and populations" (Mbembe, 2003, p. 14). For him, the colony does not imply the mobilization of sovereign subjects (or citizens) because they are inhabited by what is thought (by the colonizer) to be 'savages'. Therefore, he continues, "it is thus impossible to conclude peace with them" (Mbembe, 2003, p. 24). That is also what happens in the Terrordome, where the population is not treated as much citizens as 'savages' (by the police or the media for example) to whom common laws do not apply. The black ghetto here appears under the form of the state of exception, establishing a hierarchy of worth between individuals (those who are entitled to full rights, and those reduced to 'bare life').

\section{Possibilities of resistance}

Although he strongly disreputed the representation of slavery and the suicide of the slaves at the beginning of Welcome II the Terrordome - as being "essentially deployed here as a sign to tune black audiences onto an appropriate emotional frequency" (Gilroy, 1995, p. 18) - Paul Gilroy did also evoke in his book The Black Atlantic the case of individual or mass suicides of enslaved 
Africans, suggesting that death, in this case, could be understood as agency (Gilroy, 2002). As such, Gilroy contributes to Mbembe's formulation of death as freedom, "for death is precisely that from and over which I have power" (Mbembe, 2003, p. 39). If I will agree that slavery in the film is mostly used as a narrative device to introduce the characters and could have benefited from a more thorough exploration, I also think that in connecting the experiences of slavery with those of life in the black ghetto, Onwurah attempts to point at similar dehumanizing processes that, through necropolitics, force certain bodies to remain in a state of survival. The myth of Igbo Landing, with its numerous interpretations throughout time (with some tales talking about flying Africans, while others mention the slaves swiming back to Africa (Fee ; Webb, 2016)), has certainly long served as a symbol of resistance and empowerment. By introducing the film with this narrative, Onwurah re-presents the figure of the black slave in a position of subjecthood, reclaiming agency over his/her own life. This shift is also operated at the end of the film by the black characters: as he and his gang take over the television station, Radical assesses that "Today is the day we make war with our enemies and peace with our spirits". In violence lies therefore the potential of emancipation for Radical, and violence's political and ideological possibilities enables the filmmaker to offer a critical challenge to stereotypical images of black male violence that would be solely associated with some sort of instinctive drive. This idea of a naturally violent black masculinity, derived from colonial imaginaries, would fit the belief described earlier that the ghetto inhabitants might not be more than 'savages', a belief Onwurah firmly contests. In the film, violence occasionally stops through (what could be seen as rituals of) sex and dance. These scenes act as narrative pauses in the continuity of verbal and physical aggression that compose the film. Although both activities do not eventually prevent the fatal ending of the story, they operate as what Fanon describes referring specifically to the phenomena of dance - as "a muscular orgy during which the most 
brutal aggressiveness and impulsive violence are channelled, transformed, and spirited away" (Fanon, 2004, p. 19). For Fanon, the colonized dances "hunger, misery, violence, oppression, frustration" (Fanon, 2004, p. 19) as well as "his aspirations, his freedom, his desires of a better life" (Fanon, 2004, p. 19). The film conveys a real sensuality that is representative of Onwurah's style as a filmmaker, but that has not be noted by the critics at the time. Both Angela's dance in her living-room, and Jodie and Spike's dance at a Blue Posse party are moments of pure enjoyment, yet carry deep symbolic meanings of empowerment. Even though he is disturbed by what he calls the "obscenity of dances" (Fanon, 2008, p. 126), Fanon also points to the freeing potential of dance as preparing the people for political liberation. Whilst being a non-violent activity, during which Jodie is temporarily accepted by the black community, the dancing scene is also the beginning of an escalation of violence, with Jodie's ex-boyfriend furiously witnessing the scene and later on calling on his mob of white racist friends. When Angela's son and Jodie's unborn baby are both killed, the black gangs organize themselves around military trainings that lead them back to the path of pure violence - echoing what Fanon describes in The Wretched of the Earth when "during the struggle for liberation there is a singular loss of interest in these rituals [like dance]" (Fanon, 2004, p. 20).

The film ends on a slightly more positive note though, as the initial group of slaves whom we then found again in the Terrordome finally set foot on "the land of the ancestors", and Angela and Radical are seen breaking the chains that blocked their hands and feet. Through its panafricanist discourse, the film stresses the importance for the black community of self-pride, but also self-policing and the need for community-led media production. Malcolm X is, as one might expect, an important figure in the film - fragments of some of his speeches feature in the script but so is the African-American non-violent activist Rosa Parks (through the character of Angela's 
mother, named quite non-unequivocally Rosa Parkson), and whose symbolic presence might be a window open to a more peaceful and hopeful future.

\section{Legacy}

Welcome II the Terrordome's representations of violence are certainly transgressive and unsettling. But in fact, the film is transgressive at different levels: as Onwurah has noted, it certainly doesn't fit common expectations about what is sometimes called 'women's cinema'. The film also breaks a tradition in black British cinema of doing experimental and avant-garde work (especially in the 1980s). Onwurah has always very clearly claimed her independence from the subsidized workshops and with Welcome II the Terrordome, she was associated with the "Multiplex generation" - alongside directors Chris Jones and Paul Anderson (Roddick, 1994). Despite its 'guerrilla-style' - coming alongside its numerous technical issues - which does not exactly fit the idea one might have of multiplex cinema - Welcome to the Terrordome is unashamedly bidding for the mainstream. This all makes the film kind of an alien in British film history. So does the setting of the ghetto, which was actually quite popular in American cinema in the $1990 \mathrm{~s}^{2}$ but certainly not as much for the British film industry, at the time feeding the nation with feel-good films such as Four Weddings and A Funeral (Mike Newell, 1994) or The Full Monty (Peter Cattaneo, 1997). The fact that Onwurah shows the ghetto as a postcolonial space governed by necropolitics, where in violence, death and terror lie the possibilities of resistance and emancipation was also quite unseen and provocative. If the film received mixed reviews at the time of his release, it does have a contemporary feel that makes it still interesting to watch now, in 2018, and probably will prompt

\footnotetext{
${ }^{2}$ With films such as Boyz $n$ the Hood (John Singleton, 1991), Menace II Society (Allen \& Albert Hughes, 1993) or New Jack City (Mario Van Peebles, 1991).
} 
further analysis and readings in the future. More contemporary films, such as for example the Belgian film Black (Adil El Arbi \& Bilall Fallah, 2015, 95 minutes), do belong to this heritage of radical filmmaking. Directed by two Belgian-Moroccan men, Black tells the story of two opposite gangs fighting for power in the streets of Brussels. Depicting extreme forms of violence, the film was at first refused by distributors in France, where Belgian productions usually hope to find a broader audience. Uncompromising and raw, the film was criticized by some of the press for encouraging riots at the time of its release (RTBF, 2015), while others described it as a "cocktail of postcolonial racism" (La Libre, 2015). An unconventional work within the small Belgian film industry, Black took by surprise critics and audience alike, and showed a different side of the country's capital city. In that respect, both Black and Welcome II the Terrordome seem to belong to the same category of transgressive, radical cinema tradition (in which could figure other films such as the french La Haine (Kassovitz, 1995, 98 minutes) or the british Bullet Boy (Saul Dibb, 2005, 89 minutes). But - and despite Paul Gilroy's accusations of the film being anti-feminist - I will argue that the depiction of the experiences of the ghetto life in Welcome II the Terrordome responds to what Anne Borden would name a "genderracial" approach (Borden, 1994), an approach not used in other 'ghetto' films. Borden employs the term genderracial to account for the relationship between race and gender in the work of African-American author Langston Hughes. She describes how Hughes resists genderracial stereotypes and promote dialogue on taboo genderracial issues, "emphasizing how gender and racial identity are intertwined" (Borden, 1994, p. 333). By putting two female characters at the centre of her film (and, as a matter of fact, almost the entirety of her work), Onwurah offers a new and fresh insight that firmly puts women at the centre of the narrative, when Black for example shows quite dehumanizing representations of women (like in the rape scenes, a form of violence that does not feature in Welcome II the Terrordome). Both the racial and 
gender identity of Welcome II the Terrordome's director informs to my opinion the story and representations of the film, which stands as a real alien in this type of filmmaking tradition.

\section{Conclusion}

Ngozi Onwurah has proved to be an unconventional and often uncompromising filmmaker. With Welcome II the Terrordome, a largely self-financed first long-feature film, she has explored the issue of physical, but also institutional violence against black bodies. Throughout the film, Onwurah pays homage to her african heritage and criticizes the racialized space of the black ghetto where black lives are reduced to 'bare life'. The writings of Frantz Fanon and Achille Mbembe have helped to understand the Terrordome as a postcolonial space governed by necropolitics: in a constant state of survival, the inhabitants of the ghetto nonetheless eventually reclaim their right to exist as subjects and full citizens. And if the film has suffered a backlash from the critics at the time of its release, particularly for its depiction of interracial relationships, Jodie's narrative shows

that the film's racial politics are actually more ambivalent that it would seem at first sight. If the film has received mixed reviews in 1995, new readings in the past few years have reinstated Welcome II the Terrordome as an important piece of British Film History, still revelant to today's ongoing conversations around race.

\section{BIBLIOGRAPHY}

Beard, S. (2008) "Welcome II the Terrordome Review", Empire. Retrieved from : https://www.empireonline.com/movies/welcome-ii-terrordome/review.

Borden, A. (1994) Heroic "Hussies" and "Brilliant Queers": Genderracial Resistance in the Works of Langston Hughes, African American Review, Vol.28(3), p. 333-345. 
Ciecko, A. (1999) "Representing the Spaces of Diaspora in Contemporary British Films by Women Directors", Cinema Journal, Vol.38(3), p. 67-90.

Dorlin, E. (2007) "Décoloniser les structures psychiques du pouvoir. Erotisme raciste et postcolonie dans la pensée d'Achille Mbembe", La Découverte, Vol.3(51), p. 142-151. Translation by me.

Elley, D. (1995) "Welcome II the Terrordome", Variety. Retrieved from : http://variety.com/1995/film/reviews/welcome-ii-the-terrordome-1200440725.

Fanon, F. (2004 [1963]) The Wretched of the Earth, New-York:Grove Press. Translated by Philcox, Richard.

Fanon, F. (2008 [1952]) Black skin, White masks, New York : Grove Press. Translated by Philcox, Richard.

Fee, C.; Webb, J. (2016) American Myths, Legends, and Tall Tales: An Encyclopedia of American, Santa Barbara : ABC-CLIO

Foster, A. G. (1995) Women Film Directors: An International Bio-critical Dictionary, Wesport - London : Greenwood Press.

Foster, A. G. (1997) Women Filmmakers of the African \& Asian Diaspora: Decolonizing the Gaze, Locating Subjectivity, Carbondale : Southern Illinois University Press.

Gilroy, P. (1995) "Unwelcome", Sight and Sound, Vol.5(2), p. 18-19.

Gilroy, P. (2002 [1993]) The Black Atlantic. Modernity and Black Consciousness, London - New York : Verso.

JanMohamed, A. (2005) The Death-Bound Subject : Richard Wright's Archaeology of Death, Durham - London : Duke University Press.

La Libre (2015) Le film "Black": un cocktail de racisme postcolonial! Retrieved from : http://www.lalibre.be/debats/opinions/le-film-black-un-cocktail-de-racisme-postcolonial$565343 \mathrm{~d} 63570 \mathrm{ca} 6 \mathrm{ff} 91 \mathrm{fc} 480$.

Mayer, S. (2016) Political Animals: The New Feminist Cinema, London \& NYC: I.B. Tauris.

Mbembe, Achille (2003) "Necropolitics", Public Culture, Vol.15(1), p. 11-40. Translated by Libby Meintjes.

Mercer, K. (1988) Recoding Narratives of Race and Nation, London : Institute of Contemporary Arts.

Roddick, N. (1994) "Welcome to the Multiplex", Sight and Sound, Vol.4(6), p. 26-28. 
RTBF (2015) Incidents au Kinepolis lors de la projection du film "Black": les vidéos, Retrieved from : www.rtbf.be/info/regions/bruxelles/detail_incidents-au-kinepolis-lors-de-la-diffusion-dufilm-black-la-video?id=9133546.

Stringer, Julian (1995) "On the Rise : the Work of Ngozi Onwurah", Cineaction, p. 38-49.

Varaizdo (2017) "Ngozi Onwurah: the forgotten pioneer of Black British film", Gal-Dem, 2017. Retrieved from : http://www.gal-dem.com/ngozi-onwurah-the-forgotten-pioneer-of-black-britishfilm. 